\title{
IMPLEMENTASI PEMBELAJARAN TAJWID DAN SHOLAT DENGAN GAME ANDROID DI SEKOLAH DASAR MURSYIDAH SURABAYA
}

\author{
Arzaqillah Mubarokah' \\ IUIN Sunan Ampel Surabaya
}

\begin{abstract}
ABSTRAK
Pesatnya kemajuan teknologi berdampak pada terjadinya perubahan dalam berbagai aspek, termasuk aspek pendidikan. Proses belajar mengajar tidak hanya berfokus pada penggunaan satu atau dua buku pedoman saja, namun juga telah mengintegrasikan kecanggihan teknologi seperti gadget dan koneksi internet. Salah satunya adalah adanya pemanfaatan game android edukatif oleh pendidik dalam mata pelajaran Al-Quran Hadits (Qurdits) dan Fiqih. Tujuan dari penelitian ini adalah untuk mengetahui persepsi guru dan peserta didik terhadap penerapan game edukasi bertajuk game Tajwid Petualangan dan game fiqih Marbel (Mari Belajar) Sholat di SD Mursyidah Surabaya. Dalam penelitian ini, penulis menggunakan metode kualitatif, agar dapat mendeskripsikan penelitian secara mendalam dan mendetail. Berdasarkan hasil penelitian, penulis menyimpulkan bahwa penggunaan kedua games edukatif tersebut memberikan banyak manfaat kepada masingmasing pihak khususnya terhadap peserta didik, seperti bertambahnya minat belajar siswa, pembelajaran di kelas lebih komunikatif dan menyenangkan dan meningkatnya hasil belajar siswa. Selain itu, tantangan baru juga dirasakan oleh guru berupa: peningkatan efektifitas penggunaan game android edukatif dan pendampingan kepada siswa untuk memilih game android yang bermanfaat baik di dalam ataupun di luar kelas.

Kata Kunci: Game Android Edukatif; Game Tajwid Petualangan; Game Fiqih Sholat.

\section{ABSTRACT}

The rapid advancement of technology has an impact on changes in various aspects, including education. The teaching and learning process does not only focus on using one or two manuals, but also integrates technological advances such as gadgets and internet connections. One of them is the use of educational android games by educators in the subject of Al-Quran Hadith (Qurdits) and Fiqh. The purpose of this study was to determine the perceptions of teachers and students on the application of the educational game titled Tajwid Adventure and fiqh game Marbel (Let's Learn) Prayer at SD Mursyidah Surabaya. In this study, the authors used qualitative methods, in order to describe the research in depth and in detail. Based on the results of the study, the authors concluded that the use of these two educational games provided many benefits to each party, especially for students, such as increased student interest in learning, learning in class was more communicative and fun and increased student learning outcomes. In addition, new challenges are also felt by teachers in the form of increasing the effectiveness of using educational android games and assisting students in choosing useful android games both inside and outside the classroom.

Keywords: Educative Android Game; Adventure Tajwid Game; Fiqh Prayer Game.
\end{abstract}

\section{A. Pendahuluan}

Di era revolusi industri 4.0, banyak aspek dalam kehidupan yang mencoba menggabungkan kemajuan teknologi dalam proses pelaksanaannya. Hal itu juga dilakukan dalam dunia belajar mengajar. Para guru telah menggunakan teknologi dalam proses belajar mengajar dengan cara yang beragam. Dimulai dari penggunaan 
alat alat elektronik seperti laptop, projector dan sound atau speaker untuk membantu proses pembelajaran lebih efektif hingga adanya pembelajaran secara online dan juga pengguanaan online platform seperti Schoology atau Edmodo. ${ }^{1}$ Dengan menggunakan alat-alat bantu sederhana saja, banyak hal yang bisa dilakukan oleh pengajar seperti memutarkan video, menunjukkan gambar dan juga memperdengarkan audio yang terkait dengan pembelajaran. Penggunaan media Power Point juga sangat memudahkan guru untuk memberikan penjelasan materi yang lebih menarik karena bisa menampilkan gambar, memunculkan audio bahkan adanya animasi atau efek-efek tertentu. Namun, penerapan hal-hal di atas masih perlu diimbangi dengan kreatifitas dan inovasi pengajar nya dalam memberikan materi dan penyajian media belajar yang baik dan menyenangkan bagi para peserta didik. ${ }^{2}$ Khususnya pada mata pelajaran yang menuntut siswa untuk banyak menghafal dan melakukan praktik seperti Al-Quran Hadits dan Fiqih.

Tidak dapat dipungkiri bahwa mempelajari ilmu tajwid untuk dapat membaca Al-Quran sangatlah penting. Hal ini karena kitab Al-Quran merupakan kitab suci dalam Islam yang wajib hukumnya dibaca ketika menjalankan ibadah sholat. ${ }^{3}$ Selain mempunyai kewajiban untuk belajar membaca Al-Quran sesuai kaidah ilmu tajwid, sebagai muslim menguasai ilmu Fiqih juga salah satu hal yang diwajibkan. Ilmu Fiqih juga sangat penting untuk dipelajari karena di dalamnya terdapat bahasan tentang hukum dan praktik beribadah dan bermuamalah. Praktik beribadah seperti sholat, kemudian muamalah sendiri adalah seperti kegiatan jual beli dan semacamnya.

Namun, untuk mempelajari Al-Quran dan Ilmu Fiqih sendiri memiliki banyak aspek yang harus dipelajari, maka hal tersebut akan disesuaikan dengan jenjang pendidikan siswa. Materi yang akan diajarkan akan dimulai dari yang paling dasar hingga yang paling rumit. Misalnya di tingkat Sekolah Dasar, pelajaran yang diberikan untuk Al-Quran Hadits (Qurdits) sendiri adalah tentang hukum bacaan tajwid seperti nun mati atau tanwin bertemu dengan beberapa huruf hijaiyah. Dalam mempelajari ilmu tajwid, ada beberapa tantangan yang harus dilalui oleh para peserta didik. Setelah mengetahui dan menghafal huruf dan harakat, para murid diminta untuk mempelajari dan menghafal tata cara membaca Al-Quran secara benar sesuai kaidah

\footnotetext{
1 Nur Siyam, “Factors Impacting Special Education Teachers' Acceptance and Actual Use of Technology", Education and Information Technologies, Vol. 24, No. 1 (2019).

2 Baca, Gita Sekar Prihantini, Strategi Belajar (Malang: UMM Press, 2015).

${ }^{3}$ Khalimatus Sa'diah, “Kualitas Pembelajaran Al-Qur'an dengan Metode Tartila di TPQ Sabilun Najah Sambiroto Taman Sidoarjo", Jurnal Pendidikan Agama Islam (Journal of Islamic Education Studies), Vol. 1, No. 2 (2013).
} 
atau hukum bacaan yang sudah ditetapkan. ${ }^{4}$ Sedangkan untuk pembelajaran fiqih, peserta didik diajarkan tata cara sholat lima waktu. Pembelajaran tata sholat ini diberikan ketika mereka menempuh Pendidikan jenjang SD karena sebagai muslim, sholat adalah ibadah yang sangat penting. Untuk mempelajari tata chara sholat, ada banyak hal pula yang harus dilakukan para peserta didik. Dimulai dari menghafalkan gerakan sholat, hingga menghafalkan bacaannya dengan waktu yang disediakan.

Dalam prosesnya, guru terbiasa hanya menggunakan buku dan kitab tertentu sebagai pedoman mengajar mereka. Metode pembelajaran yang digunakan tidak lain adalah mempresentasikan atau menjelaskan materi, memberi contoh, yang kemudian dilanjutkan dengan mempraktikkan dan juga menghafal beberapa bacaan dalam sholat maupun hukum bacaan tajwid tertentu oleh peserta didik. Hal ini terbukti dalam suatu penelitian oleh Lidnillah, di mana 90\% dari respondennya mengatakan bahwa mereka hanya belajar tajwid melalui buku pedoman ilmu tajwid saja. ${ }^{5}$

Tidak bisa dipungkiri, proses pembelajaran tersebut menimbulkan rasa bosan dan malas dalam diri peserta didik untuk terus mempelajari ilmu tajwid dan fiqih karena dapat dirasakan bahwa proses pembelajarannya monoton dan kurang menarik. Tidak adanya variasi dalam metode penyampaian materi dan tidak adanya media yang menarik perhatian siswa juga berperan dalam pemupukan rasa bosan pada diri siswa. Tren pembelajaran yang berubah di zaman teknologi ini juga menuntut pendidik untuk terus beradaptasi dengan perubahan tersebut. Kreatifitas dan inovasi guru sangat diperlukan untuk membuat proses pembelajaran Qurdits dan Fiqih lebih menyenangkan, dinamis dan komunikatif, juga sesuai dengan apa yang sedang digandrungi anak-anak zaman sekarang. Oleh karena itu, penggunaan media pembelajaran yang berbeda dan menarik bisa menunjang proses pembelajaran menjadi lebih baik. ${ }^{6}$

Untuk membuat proses pembelajaran Qurdits dan Fiqih lebih mudah, banyak metode pembelajaran dan juga media pembelajaran yang telah digunakan seperti penggunaan android games di dalam proses pembelajarannya. Seiring dengan berkembangnya teknologi, telah banyak tercipta android games yang bersifat edukatif di mana para guru bisa menggunakannya sebagai media pembelajaran sesuai dengan

\footnotetext{
${ }^{4}$ Akmal Mundiri dan Irma Zahra, "Implementasi Metode STIFIn dalam Meningkatkan Kemampuan Menghafal AlQur'an di Rumah Qur'an STIFIn Paiton Probolinggo”, Jurnal Pendidikan Agama Islam (Journal of Islamic Education Studies), Vol. 5, No. 2 (2017).

${ }^{5}$ Muiz Lidnillah, Game Pengenalan Tajwid Berbasis Mobile Dengan Metode Iterative Deepening (Skripsi------ UIN Maliki Ibrahim, Malang, 2014), 9.

${ }^{6}$ Rumainur, Pengembangan Media Ajar Berbasis Multimedia (Tesis-UIN Maliki Ibrahim, Malang, 2016 ), 4. 
mata pelajaran yang mereka ampu. Penggunaan educational android games dirasa memudahkan proses belajar mengajar karena media tersebut bisa diunduh secara gratis dan bisa digunakan tanpa harus tersambung dengan internet.

Faktanya, dalam penelitian Lidnillah, diluar dari 90\% responden yang belajar hanya lewat buku, ada $3 \%$ responden yang juga belajar tajwid melalui game android. ${ }^{7}$ Seperti yang telah dilakukan seorang pengajar di SD Mursyidah Surabaya, beliau telah mencoba mengimplementasikan dua game edukasi dari android untuk membantu pembelajaran Qurdits dan Fiqih. Dalam pembelajaran Qurdits, game android edukatif yang digunakan adalah game tajwid petualangan di mana dalam game tersebut siswa akan berfokus pada hukum bacaan nun mati atau tanwin seperti Idham bighunnah, Idgham bilaghunnah, Ikhfa', Ildhar dan juga Iqlab. Sedangkan permainan Marbel (Mari Belajar) Sholat untuk mata pelajaran Fiqih, juga tidak kalah menarik untuk digunakan sebagai media pembelajaran dalam materi tata cara sholat.

Penerapan kedua game android tersebut sebagai media pembelajaran yang berbeda di SD Mursyidah Surabaya, membuat peneliti tertarik untuk mengetahui lebih jauh dan dalam tentang opini dan respon dari pendidik dan juga peserta didik terhadap implementasi game android edukatif tersebut di atas sebagai inovasi pembelajaran Qurdits dan Fiqih.

\section{B. Metode Penelitian}

\section{Jenis dan Pendekatan}

Pendekatan yang digunakan dalam penelitian ini adalah kualitatif, di mana dengan metode ini, hasil data yang didapat bisa ditafsirkan secara mendalam dan terperinci berdasarkan peristiwa atau interaksi yang terjadi oleh peneliti. ${ }^{8}$ Dengan pendekatan ini pula, partisipan diberikan porsi besar untuk memberikan data agar supaya peniliti dapat menganalisa, menginterpretasi dan menemukan ide atau teori baru dari data yang diperoleh. Dalam penelitian ini melibatkan satu pengajar dan satu kelas murid SD kelas empat di SD Mursyidah Surabaya. Langkah-langkah penelitian ini adalah 1) Observasi, 2) Wawancara dan Dokumentasi, 3) Analisis Data 4) Validasi Data.

\section{Subjek Penelitian}

Subjek penelitian ini berfokus pada seorang guru PAI dan juga murid kelas empat di SD Mursyidah. Peneliti menggunakan Teknik purposive sampling untuk

\footnotetext{
${ }^{7}$ Lidnillah, Game Pengenalan Tajwid Berbasis Mobile Dengan Metode Iterative Deepening, 9.

${ }^{8}$ Husaini Usman dan Purnomo Setiady Akbar, Metodologi Penelitian Sosial (Jakarta: Bumi Aksara, 2003 ), 81.
} 
memilih subjek penelitian berdasarkan beberapa kriteria dan pertimbangan tertentu. Untuk instrument wawancara dan observasi, peneliti memanfaatkan instrument yang sudah ada dengan sedikit modifikasi sesuai dengan kebutuhan di lapangan.

\section{Data dan Instrumen}

Dalam proses mengumpulkan data, peneliti menngunakan teknik pengumpulan data yang disesuaikan dengan responden penelitian dan karakteristik data yang akan dikumpulkan. Oleh karena itu, teknink pengumpulan yang digunakan peneliti adalah observasi, wawancara dan dokumentasi. Dengan observasi, maka peneliti bisa mengumpulkan banyak data dari fakta-fakta yang tersedia dilapangan yang bersumber dari pendidik danpeserta didik. Sedangkan melalui wawancara atau interview, peneliti dapat mengumpulkan data untuk menjawab rumusan masalah yang diajukan dalam penelitian ini. Dokumentasi sendiri berfokus ada sumber non insani yang ditujukan untuk menjawab rumusan masalah yang ketiga terkait dengan hasil/nilai dari sebelum dan sesudah pembelajaran Tajwid dan Fiqih menggunakan game Tajwid Petualangan dan Marbel Sholat.

\section{Al-Quran Hadits dan Fiqih di Sekolah Dasar}

Al-Quran Hadits dan Fiqih adalah dua dari lima mata pelajaran wajib dalam ruang lingkup PAI di Madrasah Ibtidaiya, Tsanawiyah maupun Aliyah, di mana Lembaga Pendidikan tersebut berada dibawah naungan Departemen Agama. Pada jenjang Madrasah Ibtidaiyah (MI) sendiri, Al-Quran Hadits menekankan pada kemampuan siswa untuk bisa membaca dan menulis Al-quran dan hadits. Kemudian, siswa juga diharapkan bisa menghafalkan surat-surat pendek, memiliki pemahaman makna terhadap ayat Al-Quran maupun hadits tertenu, juga mempunyai kemampuan membaca Al-Quran dengan kaidah tajwid yang benar. Ilmu tajwid sendiri adalah pengetahuan tentang kaidah-kaidah tata cara membaca Al-Quran. ${ }^{9}$ Di dalamnya, siswa akan mempelajari kaidah dasar membaca Al-Quran seperti bagaimana cara membunyikan suatu huruf hingga kaidah bagaimana caranya membunyikan huruf-huruf tersebut dalam rangkaian kata. Memahami dan mempelajari ilmu tajwid sangatlah penting karena hukum membaca Al-Quran dengan baik sesuai kaidah ilmu Tajwid adalah Fardhu 'Ain. ${ }^{10}$ Pembelajaran ilmu tajwid ini diharapkan akan bermanfaat bagi para siswa supaya mereka dapat menjaga bacaan Al-Quran mereka sejak dini. Jika

\footnotetext{
${ }^{9}$ Akhmad Yassin Andy, Ilmu Tajwid Pedoman Membaca Al Qur'an (Jombang: Pelita Offset, 2010), 1.

10 lbid., 2. 
siswa tidak dapat membaca Al-Quran dengan benar, maka hal tersebut akan juga berdampak pada ibadah sholat mereka karena mereka harus membaca surat Al-fatihah dengan benar.

Ilmu Fiqih sendiri mencakup fiqih ibadah dan muamalah. Fiqih ibadah meliputi pengetahuan terkait rukun islam yaitu tata cara bersuci, sholat, puasa, zakat dan juga berhaji. ${ }^{11}$ Sedangkan Fiqih muamalah mencakup hal-hal terkait makanan halal dan haram, khitan, qurban, jual beli dan lain-lain. ${ }^{12}$ Dalam jenjang Pendidikan MI, salah satu materi Fiqih yang wajib diajarkan adalah tata cara Sholat lima waktu. Dalam hal ini pemahaman tentang tata cara sholat akan sangat bermanfaat jika diajarkan sejak dini, agar siswa dapat mulai menghafalkan dan mempraktikkan ibadah sholat dalam keseharian mereka. Sebagai muslim, sholat adalah ibadah yang wajib dilakukan setiap harinya , di mana sholat sendiri merupakan rukun islam yang kedua, setelah Syahadat.

\section{Educational Android Games}

Tidak bisa dipungkiri, kemajuan teknologi juga mempengaruhi para pendidik dalam memilih permainan seperti apa yang akan mereka gunakan sebagai media pembelajaran dalam kelas. Permainan dengan papan (board game) adalah salah satu model permainan yang sering dimodifikasi sebagai media belajar untuk peserta didik. Namun, permainan menggunakan gadget berupa ponsel pintar khususnya android atau laptop sekarang juga mulai digandrungi masyarakat disegala usia. Banyak siswa yang sudah sangat mengenal android game melalui ponsel pintar mereka. Permainan seperti Mobile Legend sudah sangat dikuasi oleh anak-anak zaman sekarang. Namun, permainan-permainan tersebut hanya sebagai sebuah entertainment (hiburan) di mana kebanyakan para penggunanya menggunakan permainan tersebut untuk bersenangsenang diwaktu luang mereka.

Melihat tren dimasyarakat dan juga kebutuhan inovasi kegiatan pembelajaran membuat banyak guru yang mencoba menggabungkan permainan android di dalam kelas mereka. Namun, akan sangat tidak efektif jika permainan tersebut hanya sebagai hiburan, bukan sebagai media pembelajaran. Oleh karena itu, adanya android games yang bersifat edukatif atau yang akan seterusnya disebut dengan Educational Android Games akan sangat membantu proses pembelajaran peserta didik. Educational Android games sudah banyak bermunculan dengan basis berbagai macam materi pembelajaran,

\footnotetext{
11 Mahmudin, “Efektivitas Metode Demonstrasi Dalam Pembelajaran Fiqih di Madrasah Ibtidaiyah”, Jurnal Ilmiah Al-Madrasah, Vol.2, No.2 (Juni-2018): 108.

12 Ibid., 109.
} 
salah satunya adalah untuk belajar tajwid dan Fiqih. Educational Android Games ini tidak hanya bermanfaat bagi para guru sebagai media pembelajaran, tapi juga dapat digunakan untuk proses bermain dan belajar siswa diluar kelas dengan pantauan orang tua mereka.

Aplikasi Android games sendiri sangat mudah ditemukan karena mereka tersedia di play store. Permainan-permainan itu sangat mudah pula untuk diunduh ke perangkat pribadi pendidik. Aplikasi games tersebut juga sangat memudahkan proses pembelajaran karena para pengajar sudah disediakan materi dan tampilan yang menarik dari android games tersebut. Permainan menggunakan perangkat ponsel ataupun laptop tersebut bisa diakses secara online maupun offline ketika melakukan pembelajaran dikelas.

Dalam penelitian ini, peneliti berfokus pada pendidik yang memanfaatkan android games berupa Game Tajwid Petualangan dalam mengajarkan ilmu tajwid dan Game Mari Belajar (Marbel) Sholat dalam mengajarkan ilmu fiqih di SD Mursyidah Surabaya.

Permainan yang pertama adalah game tajwid petualangan, di mana peserta didik akan belajar tajwid sambil bermain. Siswa akan seolah olah berpetualng ke suatu daerah di Jawa Timur sambil mencari huruf-huruf dari hukum bacaan nun mati dan tanwin. Akan ada banyak fitur dalam permainan tersebut seperti adanya penjelasan materi sebelum melakukan permainan, adanya rintangan berupa musuh yang harus dihadapi, dan juga peserta didik bisa mengumpulkan senjata ataupun petunjuk yang bisa digunakan untuk memenangkan setiap rintangan dalam permainan tersebut. Permainan Tajwid petualangan ini mempunyai 3 tingkat level permainan, dimulai dengan mudah, sedang kemudian level terakhir, yaitu sulit. Aplikasi permainan ini bisa diakses tanpa koneksi internet. Berikut tampilan permainan Tajwid Petualangan: 


\section{Gambar 1: Tampilan Game Tajwid Petualangan}

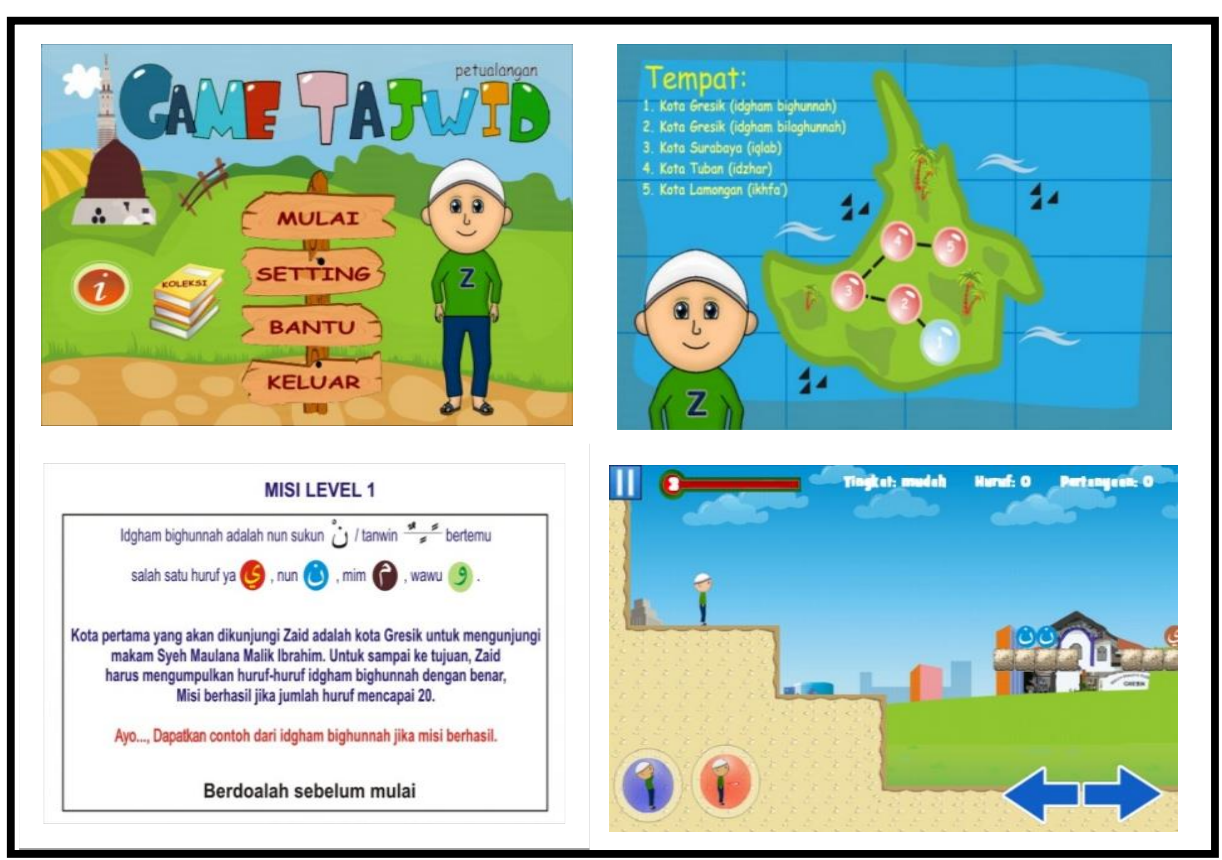

Permainan selanjutnya yang digunakan pengajar SD Mursyidah Surabaya untuk mengajarkan fiqih adalah game Marbel Sholat. Dalam permainan ini, peserta didik akan dimanjakan dengan materi sholat lima waktu, beserta gambar untuk setiap gerakan sholat nya. Selain itu, permainan ini juga memberikan fitur audio untuk suara adzan dan bacaan sholat. Aplikasi offline ini menggunakan tipe permainan matching, di mana siswa akan diminta untuk mencocokkan gerakan sholat dan bacaannya. Berikut adalah tampilan permainan Marbel Sholat:

\section{Gambar 2: Tampilan Game Marbel Sholat}

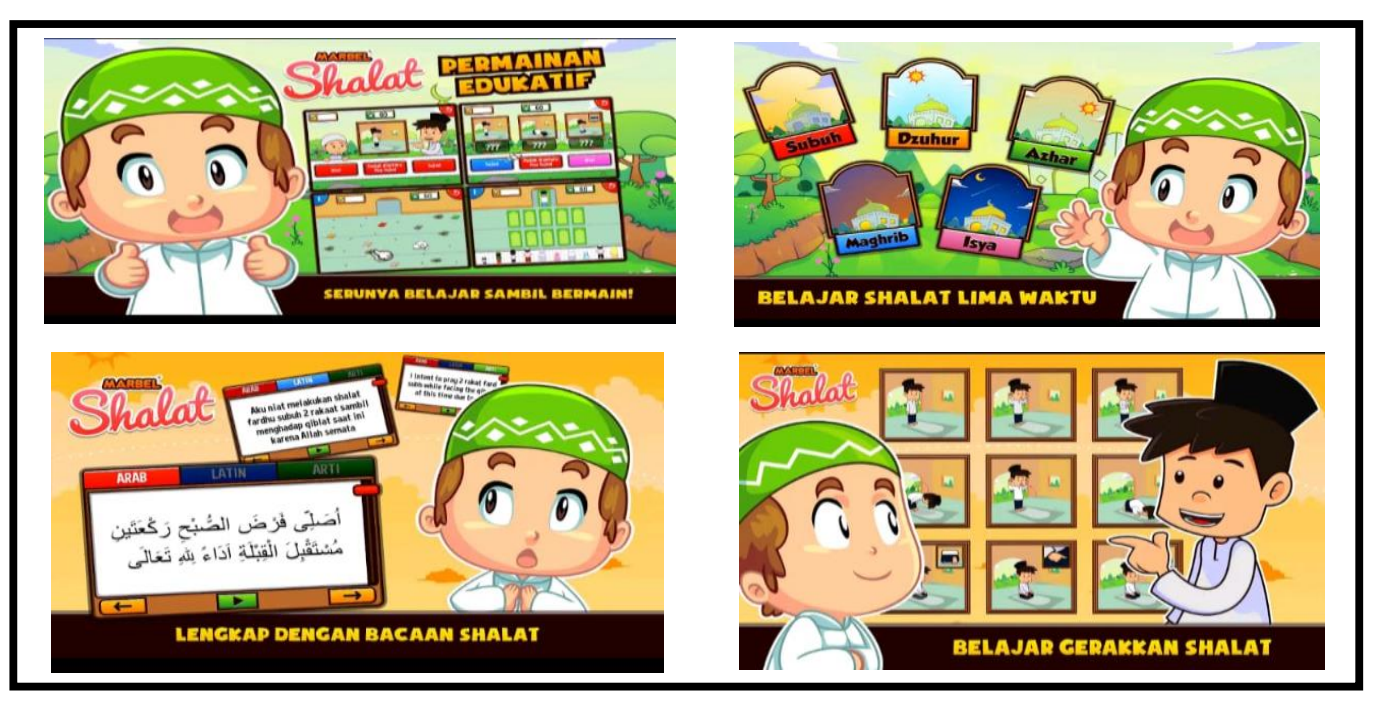


Melalui media permainan di atas, guru dapat memanfaatkannya sebagai pengganti buku pelajaran dan juga power point karena di dalam game tersebut, sudah tersedia penjelasan materi yang disajikan dengan gambar berwarna. Hal ini dapat sangat membantu pengajar untuk menarik perhatian siswa.

\section{E. Implementasi Pembelajaran Tajwid dan Sholat dengan Game Android}

Dapat diartikan secara sederhana, implementasi adalah suatu penerapan atau suatu pelaksanaan dari suatu kebijakan atau program tertentu. Secara lebih lengkap, Varn Horn mendefinisikan implementasi sebagai tindakan yang dilakukan oleh secara individu ataupun berkelompok, yang bisa berasal dari pemerintah maupun swasta, yang mana mempunyai tujuan untuk mencapai tujuan yang telah ditetapkan. ${ }^{13}$ Dalam proses penerapannya, ada sekurang-kurangnya empat hal penting untuk dimiliki, yaitu: ${ }^{14}$ 1) Faktor lingkungan, di mana untuk mengimplementasikan suatu program atau kebijakan, pelaksana harus memperhatikan faktor lingkungan termasuk fisik, sosial daya dan politik, 2) Adanya target grup, yaitu kelompok yang dijadikan sasaran sebagai penerima manfaat dari kebijakan atau program yang diterapkan, 3) Adanya program atau kebijakan itu sendiri, 4) Adanya pihak pelaksana atau implementer, baik perorangan maupun organisasi yang bisa bertanggung jawab dari awal hingga akhir proses implementasi.

Dalam penelitian ini, seorang pengajar sudah mengimplementasikan educational android games berupa Game Tajwid Petualangan dan Marbel Sholat dalam proses mengajarnya. Kedua games tersebut memberikan kemudahan untuk proses belajar mengajar karena bisa digunakan sebagai sarana bermain sekaligus belajar. Dalam proses implementasi kedua games android ini, peneliti mengadaptasi tiga siklus yang dilakukan oleh Ronan Kelly dalam penelitiannya yang berjudul "Penggunaan Instagram untuk Mengembangkan Keterampilan Bermain dan Belajar" yaitu, 1) meminta peserta memperbarui permainan android disetiap pertemuan, 2) memberikan umpan balik, 3) melakukan wawancara tentang permainan yang telah dilakukan dalam teks deskriptif. Peneliti disini juga menambahkan kegiatan lain dalam siklus ini yaitu memberikan permainan untuk membuat siswa lebih antusias dalam belajar menlis teks deskriptif.

\footnotetext{
${ }^{13}$ Budi Winarno, Kebijakan Publik: Teori \& Proses (Jakarta: PT. Buku Kita, 2006), 155.

14 Ibid., 167.

El Banat Vol. 10 No. 1 (2020)
} 
Dalam penelitian ini, peneliti melakukan tiga kali observasi untuk mengetahui dan memperoleh data tentang sekolah dan juga melihat sendiri bagaimana kedua game android (game tajwid petualangan dan marbel sholat) diaplikasikan pada pembelajaran Qurdits dan Fiqih. Format pertanyaan dalam wawancara adalah open question, di mana responden bisa memberikan informasi secara lebih luas. Setelah itu, peneliti melakukan wawancara terhadap guru PAI dan siswa kelas IV untuk mendapatkan jawaban mengenai kesan dan tanggapan mereka terhadap penerapan media belajar ini. Setelah itu, data dianalisis dan juga divalidasi. Berikut adalah hasil temuan dari proses wawancara tersebut:

\section{Persepsi Guru terhadap Pembelajaran Tajwid dan Fiqih dengan Media} Pembelajaran Android Games

Di dalam penelitian ini, persepsi pendidik maupun peserta didik terhadap pembelajaran menggunakan media android games akan digunakan oleh peneliti sebagai data yang akan ditafsirkan dan juga ditelaah yang diintegrasikan dengan teori-teori terkait. Dalam prosesnya, persepsi guru merupakan proses aktif yang juga berperan penting, bukan hanya mengenai stimulus yang diterima, tapi juga sebagai individu yang memiliki pengalaman yang digunakan sebagai motivasi dan melalui sikapnya terhadap stimulus yang diterima. ${ }^{15}$ Oleh karena itu, dapat disimpulkan bahwa persepsi guru adalah hasil dari proses pemberian makna atau penafsiran suatu peristiwa atau informasi oleh sebagai pendidik. Dalam hal ini adalah proses implementasi media pembelajaran Game Tajwid Petualangan dan juga Game Marbel Sholat.

Terkait dengan penerapan kedua games android ini, bisa disimpulkan bahwa pengajar menikmati proses mengajarnya. Hal ini dapat dilihat dari apa yang disampaikan oleh pengajar dalam kutipan wawancaranya ketika diminta pendapat perihal implementasi dua games android diatas:

"Saya sangat senang, karena seperti yang mbak lihat, anak-anak terlihat enjoy, menikmati dan dengan media Games Tajwid Petualangan ini, saya merasa terbantu untuk membuat metode mengajar yang variatif tentunya di dukung dengan perlengkapan atau alat pendukung yang ada di sekolah"16

Pengajar merasa senang karena melihat peserta didik yang juga sepertinya merasakan hal yang sama, terlihat dari perubahan sikap peserta didik selama pembelajaran. Adanya antusiasme dan keaktifan yang lebih dari biasanya membuat

\footnotetext{
15 Melkianus Suluh, "Persepsi Guru dan Peserta Didik Terhadap Proses Pembelajaran Flsika Berdasarkan Kurikulum 2013”, Jurnal Penelitian dan Pengkajian Ilmu Pendidikan e-Santika, Vol.2, No.2 (Juni-2019): 64.

${ }^{16}$ M. Imron, Wawancara, Surabaya, 1 Maret 2020.
} 
pengajar lebih senang dan bersemangat. Proses pembelajaran juga dirasakan lebih ringan dan mudah dengan adanya games ini karena sedikit meringankan pekerjaan pengajar di dalam kelas.

"Sama seperti games Tajwid Petualangan mbak, media games android ini selain mudah di akses karena offline dan media Games Marbel sholat ini lebih komplit mbak, karena selain games, diaplikasi ini disajikan bacaan adzan, suara adzan, bacaan sholat beserta suara lafadz dan gerakannya. Lalu yang terakhir ada gamesnya. Jadi media ini sangat menarik perhatian anak-anak buat kepo istilahnya mbak. Dan bacaannya sesuai untuk sekolah MI Al-Fatich yang mengikuti sekolah Ma'arif NU."17

Dengan adanya media games ini, guru tidak perlu banyak mencontohkan bagaimana cara membaca suatu bacaan, ataupun memberikan contoh yang berulang-ulang karena terbantu gambar ataupun materi yang tersedia dalam game tersebut di atas. Khusunya untuk game Marbel Sholat, adanya audio suara adzan dan bacaan setiap gerakan sholat sangat membantu pengajar di dalam penyampaian materi. Dengan tampilan dan fitur yang menarik, games tajwid petualangan dan Marbel sholat dapat menarik minat siswa untuk belajar dan bermain melalui games ini. Dapat disimpulkan demikian karena peserta didik terlihat sangat tertarik dan ingin tahu lebih banyak tentang permainan yang sedang mereka lakukan dan bagaimana akhir permainan itu seperti apa yang disampaikan pengajar dalam wawancaranya.

"Jadi media ini sangat menarik perhatian anak-anak buat kepo istilahnya mbak. Walaupun demikian, saya tidak serta merta melepaskan tanggung jawab untuk menjelaskan dan memberikan umpan balik terhadap apa yang mereka pelajari di dalam kelas.."18

Penjelasan atau highlight materi dari pengajar tetap berperan sangat penting dalam pembelajaran karena dalam proses ini guru dapat mengukur pemahaman siswa, memberi kesimpulan juga meluruskan pemahaman siswa jika ada yang salah dipahami. Namun, dibalik banyaknya manfaat yang dirasakan, pengajar juga merasakan adanya tantangan baru yang dihadapi ketika menerapkan kedua games tersebut.

"Laah tantangannya adalah bagaimana membuat games ini bisa efektif di kelas, memberikan efek yang lebih baik kepada anak-anak mulai dari pemahaman pada materi tajwid dan fiqih, meningkatkan nilai peserta didik bahkan apakah bisa dari games ini anak-anak jadi sosok millennial yang faham materi agama,... ." 19

Salah satu tantangannya adalah bagaimana caranya penggunaan permainanpermainan di atas lebih efektif. Adanya penerapan media game ini tentunya

\footnotetext{
${ }^{17}$ M. Imron, Wawancara, Surabaya, 4 Maret 2020.

${ }^{18}$ M. Imron, Wawancara, Surabaya, 16 Maret 2020.

${ }^{19}$ M. Imron, Wawancara, Surabaya, 20 Maret 2020. 
membuat siswa sangat antusias dan fokus terhadap game tersebut. Dapat disimpulkan bahwa yang ditakutkan pengajar adalah ketika murid-murid hanya tertarik pada model permainan nya saja dan melupakan apa yang seharusnya mereka pelajari. Hal ini bisa terjadi karena kesempatan ini adalah yang pertama kalinya bagi mereka untuk mengenal dan mengetahui game tajwid petualangan dan juga marbel sholat. Oleh karena itu, pengajar merasa ini adalah sebuah tantangan di mana beliau harus bisa menggunakan media tersebut benar-benar sebagai sarana belajar yang bisa memberikan efek yang positif bagi pemahaman siswa dan juga nilai ulangan peserta didik.

Secara lebih detail, untuk game Marbel Sholat sendiri, pengajar dihadapkan pada rasa bosan yang dialami siswa jika permainan tersebut dilakukan berulang kali.

"Jadi kalau games marbel sholat itu hanya games tebak, gambar, bacaan dan sof sholat, ... Jadi kadang kalau games marbel sholat itu kalau di ulang, membuat anakanak sedikit bosan. Karena merasa sudah tau." 20

Hal ini dikarenakan tipe permainan di dalam game ini hanya menebak gambar, bacaan sholat dan juga sof dalam sholat. Tidak ada tantangan atau langkah-langkah sulit untuk menyelesaikan permainan seperti dalam game Tajwid Petualangan. Game marbel sholat sendiri tidak mempunyai perbedaan level untuk memainkannya.

Tantangan lain yang coba ditaklukkan oleh pengajar SD Mursyidah ini adalah mengenalkan aplikasi-aplikasi seperti ini untuk mengenalkan kepada siswa, hal-hal baru dalam teknologi masa sekarang.

“...meningkatkan nilai peserta didik bahkan apakah bisa dari games ini anak-anak jadi sosok millennial yang faham materi agama, millennial disini dimaksudkan anakanak tidak menjadi kolot, tidak faham tentang teknologi. Tapi anak-anak sekarang faham dengan mobile legend, jadi tantangan nya lagi adalah bagaimana membuat anak-anak ini bisa lebih cenderung senang dengan game edukatif."21

Tidak banyak dari mereka yang mempunyai ponsel pintar dan tahu cara menggunakannya dengan efektif. Oleh karena itu, pendidik berharap dengan adanya penggunaan aplikasi game android ini dapat membuat siswa sadar akan kemajuan teknologi yang berkembang saat ini. Selain itu, bagi para siswa yang mempunyai ponsel pintar, sangat diharapkan dengan adanya penggunaan media belajar seperti ini, mereka akan bisa lebih selektif dalam memilih permainan yang akan mereka mainkan kedepannya. Yaitu dengan memilih permainan yang tidak hanya digunakan sebagai sarana hiburan, namun juga sebagai sarana belajar diluar kelas.

\footnotetext{
${ }^{20}$ M. Imron, Wawancara, Surabaya, 29 Maret 2020.
}

${ }^{21}$ M. Imron, Wawancara, Surabaya, 14 Maret 2020. 
Pertanyaan terkait sumber belajar juga ditanyakan pada pengajar.

"Kebetulan yang saya pakai selain buku pegangan guru dari maarif ada juga kitab syifaul jinan, buku panduan tajwid, LKS."22

Pengajar SD Mursyidah ini selain menggunakan buku panduan dari sekolah, beliau juga menggunakan kitab syifaul jinan, buku panduan tajwid dan buku LKS untuk memfasilitasi siswa sebuah pembelajaran dengan materi yang lengkap dari berbagai sumber.

Penggunaan media android games juga memberikan perbedaan yang signifikan bagi pengajar salah satunya adalah kemudahan yang diberikan.

"Jelas beda mbak, android games itu kan basisnya kayak media modern atau TIK kalau bahasa sekarang, dibandingkan dengan media manual jelas beda...., tapi kalau pakai media android games ini sangat membantu karena selain tidak repot anakanak juga senang dengan desain aplikasinya, materi di aplikasinya juga jelas. Kalau media manual itu kebanyakan ribet dan perlu mengeluarkan uang. Lah kalau berbasis teknologi gini kan tinggal memanfaatkan yang ada saja."

Dapat diambil kesimpulan, bahwa jika dibandingkan dengan media pembelajaran manual atau tradisional yang dulu beliau aplikasikan, di mana pengajar membuat dan mendesain media pembelajaran mereka sendiri sesuai kebutuhan, android games memberikan hal tersebut tanpa harus mengeluarkan uang and menghabiskan tenaga maupun waktu untuk mempersiapkannya. Pengajar tidak perlu repot memikirkan ide dan cara penerapannya dalam sebuah media belajar. Pengajar hanya perlu masuk ke play store, menngunduh aplikasi dan mempelajarinya sebelum kelas dilaksanakan. Pendidik juga diuntungkan dengan fitur materi yang lengkap dan visual yang menarik untuk dilihat anak-anak. Namun, ketersediaan Laptop, Projector dan juga speaker memang dibutuhkan untuk melancarkan proses pembelajaran menggunakan android games ini. Dengan demikian, dapat disimpulkan pula bahwa kemudahan ini dapat memberikan dampak yang luar biasa pada guru, karena mereka dapat memindahkan waktu yang dulunya dipakai untuk mendesain media, untuk digunakan pada hal lain yang juga penting dilakukan seperti lebih fokus pada murid yang belum mencapai target maupun mempersiapkan kelas-kelas berikutnya.

Perubahan signifikan juga ditunjukkan oleh peserta didik selama proses pembelajaran menggunakan game tajwid petualangan dan marbel sholat ini. Seperti yang telah disebutkan, bahwa siswa sangat menunjukkan minat dan antusiasme mereka untuk belajar tajwid dan fiqih menggunakan android game ini. Mereka juga

${ }^{22}$ M. Imron, Wawancara, Surabaya, 14 Maret 2020.

El Banat Vol. 10 No. $1(2020)$ 
memberikan respon positif selama pembelajaran yang terlihat pula melalui hasil belajar mereka yang lebih baik dalam ulangan harian mereka.

“...Nilai anak-anak selama ada ulangan harian lebih meningkat, karena memang dari awal niat saya memakai media ini karena ada faktor nilai anak-anak yang belum ada perubahan signifikan."23

Penggunaan android games ini tidak serta merta muncul dalam proses pembelajaran di SD Mursyidah ini. Inovasi ini diperoleh setelah pengajar melakukan refleksi.

“... Karena beberapa tahun terakhir saya menyadari mbak, proses pembelajaran saya ini terbilang membosankan. Saya merasakan sendiri anak-anak seperti tidak semangat saat pelajaran dan mintanya menonton video kisah nabi, ... Jadi saya cari solusi bagaimana pelajaran Qurdist ini tidak selalu menghafalkan, mengerjakan soal. Apalagi materi fiqih, materi fiqih adalah salah satu materi yang kebanyakan praktik. Jadi harus ada media penyambung untuk memahamkan mereka." 24

Proses pembelajaran yang dianggap monoton dan kurang inovasi karena berputar pada proses presentasi, praktik, latihan soal dan menghafal, membuat guru PAI di SD Mursyidah ini berpikir untuk merubah cara mengajarnya dengan membuat inovasi atau kreatifitas baru dalam proses pembelajaran yang beliau lakukan. Kurang nya semangat belajar peserta didik juga memperkuat niat beliau untuk merubah metode belajar dan mengajar.

Diawali dengan kesadaran pengajar terhadap antusias peserta didik dalam bermain mobile legend, beliau mulai mencari game edukasi yang tersedia di play store. Pada akhirnya, setelah mencoba mencari dan memilih dari berbagai macam aplikasi yang ada, beliau menemukan game tajwid petualangan dan Marbel Sholat untuk diunduh dan diterapkan di kelas beliau.

\section{Persepsi Peserta Didik terhadap Proses Pembelajaran Tajwid dan Fiqih dengan Bantuan Android Games}

Selain persepsi dari pengajar, penelitian ini juga memberikan ruang yang luas untuk mengetahui persepsi peserta didik terhadap media pembelajaran berupa android games yang sudah diaplikasikan. Data didapat dari wawancara yang dilakukan oleh peneliti. Melalui hasil wawancara terkait dengan pendapat siswa terhadap penerapan media games android ini, bisa diketahui bahwa penggunaan media pembelajaran selain buku memberikan suasana baru yang menyenangkan bahkan seru bagi para murid.

\footnotetext{
${ }^{23}$ M. Imron, Wawancara, Surabaya, 12 Maret 2020.

${ }^{24}$ M. Imron, Wawancara, Surabaya, 14 Maret 2020.
} 
“Jadi enak pakai games kak, seru. Kalau pakai buku terus loh bosan. Nanti di suruh menghafalkan terus." 25

Siswa dapat berpendapat demikian karena media yang selalu mereka gunakan untuk belajar adalah buku, dan kegiatan yang selalu dilakukan adalah menghafal dan mengerjakan soal latihan. Oleh karena itu, penggunaan media lain yang berbeda sangat berdampak pada suasana kelas. Atmosfir yang berbeda dan segar dapat dirasakan oleh para peserta didik.

Namun, peserta didik juga dapat merasakan bahwa jika hanya mengandalkan permainan di atas untuk bisa memahami materi yang diajarkan, pemahaman yang mereka dapatkan tidak akan sempurna.

"Faham kak kalau sama dijelasin pak imron, kalau tidak dijelaskan kadang faham kadang tidak faham."26

Seperti yang telah dibahas sebelumnya, karena media ini berupa game, maka para siswa juga akan merasa bahwa mereka sedang bermain, bukan belajar. Oleh karena itu, penjelasan tambahan, penguatan materi dan juga umpan balik dari pendidik sangatlah dibutuhkan dalam setiap penerapan android games ini untuk memastikan bahwa siswa paham dengan apa yang mereka pelajari.

Tantangan dalam penerapan media pembelajaran ini, tidak hanya dirasakan oleh pendidik namun juga dirasakan oleh peserta didik. Tantangan yang dirasakan peserta didik terjadi ketika mereka diminta untuk mengerjakan atau memainkan permainan tersebut.

"Kesulitan nya pas bermain terus ada waktunya, soalnya aku sering habis waktunya."27

Yang terjadi adalah peserta didik merasa kesulitan mengerjakan soal tersebut dengan waktu otomatis yang disediakan oleh aplikasi permainan tersebut. Berbeda dengan pemberian soal Latihan manual oleh guru, yang mana waktu pengerjaan soal latihan bisa lebih fleksibel, pengerjaan soal di dalam android games ini sudah ada ketetapan waktu atau batas waktu maksimal untuk setiap Latihan yang disediakan. Karena peserta didik belum terbiasa dengan pengerjaan soal Latihan diwaktu yang singkat, mereka mengalami kesulitan dalam mengatur waktu mereka menyelesaikan soal Latihan yang diberikan. Namun, dapat disimpulkan bahwa para siswa tidak mengalami kesulitan yang berarti karena hal ini bisa diminimalisir dengan penjelasan dari guru terkait untuk memperkuat

\footnotetext{
${ }^{25}$ Najwatul Mufidah, Wawancara, Surabaya, 14 Maret 2020.

26 Nasywa Zahira, Wawancara, Surabaya, 2 Maret 2020.

27 Thalita Ifthina Zafira, Wawancara, Surabaya, 5 Maret 2020. 
pemahaman siswa. Kemudian, pendidik juga dapat membiasakan siswa mengerjakan Latihan dalam android games tersebut, agar siswa dapat berlatih berpikir dengan cepat ketika latihan.

Dalam penerapannya kedua permainan ini memberikan kesan yang sangat positif dan melekat pada siswa. Secara lebih spesifik, permainan Tajwid Petualangan dan Marbel Sholat memberikan kesan menyenangkan dan seru bagi para siswa karena mereka diberikan kesan "bermain games" di dalam kelas seperti apa yang disampaikan salah seorang responden.

"Enak kak, bisa nge-games di sekolah. Soalnya kan setiap hari selalu mengerjakan soal tematik, matematika. Lah kalau pelajaran nya pak imron seneng gitu soalnya orange lucu juga." 28

Kegiatan pembelajaran yang tidak menuntut siswa untuk mengerjakan soal latihan maupun menghafal seperti ini, menumbuhkan ketertarikan dan minat belajar yang tinggi dari para siswa. Selain itu, permainan Marbel sholat yang diterapkan di kelas Fiqih juga sangat menarik perhatian peserta didik.

"Seru juga kalau pakek games marbel sholat, soalnya gambarnya lucu, terus animasinya bagus kayak lihat film."29

Hal ini, diperkuat juga oleh respon siswa lainnya,

“lya kak suka soalnya kan gamesnya menyenangkan dan ada suaranya kalau semisal bacaan ruku' bacaan sujud gitu." 30

Banyak sekali siswa yang menyatakan bahwa game marbel sholat memiliki gambar dan animasi yang menarik karena lucu dan penuh warna. Audio suara adzan dan juga bacaan setiap Gerakan sholat yang digunakan sebagai contoh bagaimana cara membaca bacaan sholat dengan benar, juga memberikan kesan baru dan menarik bagi mereka. Sudah terlalu sering disuguhkan contoh dari pengajar pasti membuat siswa menginginkan hal baru, hingga pada akhirnya audio di game Marbel Sholat ini membuat mereka antusias. Oleh karena itu, sangat bisa diambil kesimpulan bahwa peserta didik sangat menyukai penerapan media android games ini dalam pembelajaran tajwid dan fiqih mereka karena menyenangkan dan berbeda dari apa yang biasanya mereka lakukan di dalam kelas.

\footnotetext{
${ }^{28}$ M. Andhika, Wawancara, Surabaya, 12 Maret 2020.

${ }^{29}$ M. Zainul Musthofa, Wawancara, Surabaya, 24 Maret 2020.

${ }^{30}$ Faruq Akmal Maulidin, Wawancara, Surabaya, 14 Maret 2020.
} 
3. Hasil Belajar Peserta Didik Sebelum dan Sesudah Penerapan Game Tajwid Petualangan dan Marbel Sholat

Untuk mengetahui hasil dari penerapan android games ini, pendidik membandingkan nilai peserta didik sebelum dan sesudah menggunakan media pembelajaran ini. Nilai peserta didik untuk Ilmu tajwid dan fiqih didapatkan dari dua tugas yang berbeda, yaitu tugas tertulis dan juga tugas praktik. Dalam penelitian ini, tugas tertulis dan praktik sebelum penerapan akan disebut dengan tugas 1 dan praktik 1 , sedangkan tugas tertulis dan praktik sesudah penerapan akan disebut dengan tugas 2 dan praktik 2. Tugas tertulis merupakan tugas menjawab pertanyaan dalam bentuk pilihan ganda maupun essay. Tugas dalam bentuk ini diperuntukkan untuk mengetahui kemampuan siswa dlam memahami materi secara tertulis. Penilaian tugas tertulis 1 dan 2 sendiri dimulai dari 10-100 di mana nilai Kriteria Kelulusan Minimal (KKM) nya adalah 75. Sedangkan tugas praktik adalah di mana peserta didik diminta untuk mempraktikkan cara membaca hukum bacaan ilmu tajwid dan juga tata cara sholat. Tugas ini diperuntukkan untuk mengetahui apakah siswa dapat mengaplikasikan bacaan tajwid berupa hukum nun mati dan tanwin dan cara cholat dengan baik dan sempurna. Nilai untuk praktik 1 dan 2 dimulai dari skala $A$ hingga $D$, di mana nilai $A=92-100, B=82-92, C=75-2$, and $D=<75$.

Untuk pelajaran Qurdits, peserta didik mempelajari ilmu tajwid yang berfokus pada hukum nun mati dan tanwin yaitu idham bigunnah, idgham bilagunnah, idhar, ikhfa' syafawi dan juga iqlab. Untuk tugas 1 yakni di mana siswa belum menggunakan media permainan android, mereka diminta untuk mengerjakan soal dari buku pegangan siswa (Lembar Kerja Siswa), sedangkan praktik 1, mereka diminta untuk membaca dan mencari hukum bacaan tertentu dari hukum nun mati dan tanwin di Al-Quran atau buku pelajaran mereka. Contohnya, mereka akan diminta mencari dan membaca hukum bacaan Idhar dalam surat Ad-Dhuha. Peserta didik akan dinilai dari cara mereka membaca hukum bacaan tersebut.

Untuk tugas 2, di mana siswa sudah belajar menggunakan media games tajwid petualangan, mereka diminta untuk mengerjakan soal yang ada di dalam games tersebut. Sedangkan untuk praktik 2, siswa akan dinilai dari bagaimana cara siswa bermain menggunakan games tajwid petualangan itu sendiri.

Berikut hasil dari tugas tertulis dan tugas praktik Qurdits: 


\begin{tabular}{|c|c|c|c|c|}
\hline \multirow{2}{*}{ No } & \multirow{2}{*}{ Nilai Tugas } & \multirow{2}{*}{ Frekuensi } & \multicolumn{2}{|c|}{ Presentase } \\
\cline { 4 - 5 } & & & $\begin{array}{c}\text { Sebelum } \\
\text { (1) }\end{array}$ & $\begin{array}{c}\text { Sesudah } \\
\text { (2) }\end{array}$ \\
\hline \multirow{2}{*}{ 1) } & \multirow{2}{*}{ Tugas Tertulis } & $>85$ & $59,4 \%$ & $70,2 \%$ \\
\hline \multirow{2}{*}{ 2) } & Tugas Praktik & $<85$ & $40,5 \%$ & $29,7 \%$ \\
\hline & & $\mathrm{A}$ & $51,3 \%$ & $70,2 \%$ \\
\hline & & $\mathrm{B}$ & $48,6 \%$ & $29,7 \%$ \\
\hline
\end{tabular}

Tabel 1. Nilai peserta didik dalam pelajaran Qurdits

Melalui tabel perbandingan di atas, dapat disimpulkan bahwa setelah penerapan Game Tajwid Petualangan dalam proses belajar dikelas, hasil tugas atau ulangan tertulis siswa meningkat. Hal ini dibuktikan pada kategori nilai $>85$, ada peningkatan sekitar $10 \%$ dari $59,4 \%$ menjadi $70,2 \%$. Artinya, peserta didik bisa menjawab soal Latihan lebih baik setelah implementasi game android ini sehingga nilai mereka meningkat. Peningkatan poin dari nilai mereka juga bergam, dimulai dari poin kenaikan terkecil yaitu 2 hingga kenaikan mencapai 10 poin. Dengan adanya peningkatan pada kategori $>85$, maka akan secara otomatis mengurangi presentasi pada kategori <85. Hal ini mencerminkan bahwa penggunaan media android games ini memberikan efek yang positif, di mana sebelumnya ada 15 peserta didik mendapatkan nilai <85, kini hanya ada 11 peserta didik dalam kategori tersebut.

Peningkatan sekitar 20\% juga terjadi pada tugas praktik peserta didik untuk kategori nilai A, di mana sebelum adanya penerapan media game ini, hanya 51,3\% saja siswa yang mendapatkan nilai A pada praktik menemnukan dan membaca hukum bacaan nun mati dan tanwin. Namun setelah adanya penerapan media game Tajwid petualangan, ada penambahan 7 siswa dalam kategori nilai A hingga presentase nya naik hingga 70. Secara otomatis pula, presentasi katgori nilai $B$ menurun sekitar $10 \%$ dari presentase sebelum pengggunaan media android game ini.

Untuk pelajaran Fiqih sendiri, peserta didik belajar tata cara sholat beserta bacaan nya. Dimulai dari gerakan dan bacaan takbiratul ihram hingga salam. Untuk tugas 1 , peserta didik diminta untuk mengerjakan soal pilihan ganda dan essay yang bersumber dari buku pegangan mereka atau Lembar Kerja Siswa. Sedangkan setelah penerapan game Marbel Sholat, peserta didik diminta untuk menjawab soal 
berbentuk pilihan ganda dan juga mencocokkan gambar dan bacaan yang terdapat di dalam game Marbel Sholat.

Sedangkan penilaian tugas praktik 1 dan praktik 2 diambil dari kegiatan siswa mempraktikkan salah satu sholat lima waktu secara sempurna. Yang membedakan antara tugas praktik 1 dan 2 adalah adanya penerapan games android dalam proses pembelajaran sebelum melakukan ujian praktik ke 2 .

Berikut hasil dari tugas tertulis dan tugas praktik Fiqih:

\begin{tabular}{|c|c|c|c|c|}
\hline \multirow{2}{*}{ No } & \multirow{2}{*}{ Nilai Tugas } & \multirow{2}{*}{ Frekuensi } & \multicolumn{2}{|c|}{ Presentase } \\
\cline { 3 - 5 } & & & $\begin{array}{c}\text { Sebelum } \\
(1)\end{array}$ & $\begin{array}{c}\text { Sesudah } \\
(2)\end{array}$ \\
\hline \multirow{2}{*}{$1)$} & \multirow{2}{*}{ Tugas Tertulis } & $>85$ & $62,1 \%$ & $81 \%$ \\
\cline { 3 - 5 } & \multirow{3}{*}{$2)$} & $<85$ & $37,8 \%$ & $18,9 \%$ \\
\hline \multirow{2}{*}{} & Tugas Praktik & $\mathrm{A}$ & $51,3 \%$ & $72,9 \%$ \\
\cline { 3 - 5 } & & $\mathrm{B}$ & $40,5 \%$ & $27 \%$ \\
\hline & & $\mathrm{C}$ & $8,1 \%$ & - \\
\hline
\end{tabular}

Tabel 2. Nilai peserta didik dalam pelajaran Fiqih

Dalam tabel perbandingan nilai di atas, dapat kita lihat bahwa presentasi nilai siswa meningkat ke kategori nilai yang lebih baik yaitu kategori nilai $>85$ dan juga kategori nilai A. Untuk tugas tertulis di mata pelajaran Fiqih ini, 81\% siswa mendapatkan nilai > 85 yang mana presentase tersebut 18\% lebih tinggi dari sebelum penerapan game Marbel Sholat. Dengan kata lain, setelah penerapan android game ini, ada 30 siswa yang bisa mencapai nilai $>85$, di mana nilai tersebut mendekati seluruh jumlah murid yaitu 37 siswa. Hal ini juga berarti, adanya penurunan pada nilai dibawah 85 karena para siswa berhasil meningkatkan nilai mereka. Penurunan presentase kategori < 85 terjadi hingga setengah dari presentase nilai sebelum adanya penerapan ini. Poin kenaikan yang mereka dapat juga beragam seperti yang terjadi pada nilai ilmu tajwid, dimulai dari 1 hingga 10 poin kenaikan. Namun, ada pula 3 siswa yang nilainya tidak mengalami kenaikan maupun penurunan, dan ada seorang siswa yang mengalami penurunan nilai 1 poin. Tapi hal tersebut tidak membuat nilai mereka jatuh dibawah KKM.

Hal serupa juga terjadi pada nilai praktik sholat siswa. Jika sebelum menggunakan game Marbel sholat nilai peserta didik bergam mulai dari A hingga $C$, setelah implementasinya, nilai siswa hanya berkutat pada A dan B saja, yang mana 
perubahan ini adalah perunahan yang positif. Artinya, tidak ada dari siswa tersebut yang mendapatkan nilai 75 atau sesuai dengan Kriteria Kelulusan Minimal (KKM). Semua siswa mampu mendapatkan nilai di atas nilai KKM. Pada awalnya, ada sekitar 8\% siswa yang mendapatkan nilai C, dan setelah penerapannya, tidak ada sama sekali siswa yang mendapatkan nilai tersebut. Kategori nilai B juga mengalami penurunan sekitar $13 \%$ yang setara dengan 5 orang siswa. Dengan adanya banyak penurunan dari kategori nilai B dan C, maka secara otomatis kenaikan nilai siswa menjadi A bisa dibuktikan dengan meningkatnya presentasi kategori tersebut hingga $72,9 \%$.

Oleh karena itu, dapat disimpulkan bahwa implementasi game android tajwid petualnagan dan marbel sholat tidak hanya meningkatkan nilai siswa pada ujian tertulis, namun juga tugas praktik mereka di mana nilai mereka berada di atas nilai Kriteria Kelulusan Minimal (KKM) yaitu 75. Hal ini merupakan kabar baik baik guru pengampu PAI di SD Mursyidah itu sendiri.

\section{F. Kesimpulan}

Setelah melalui proses penelitian disertai dengan hasil ulangan para siswa, dapat disimpulkan bahwa penerapan android games tajwid petualangan dan Marbel (Mari belajar) sholat memberikan dampak positif bagi siswa. Manfaat positif yang dirasakan diantaranya adalah meningkatnya minat dan motivasi belajar dan partisipasi siswa dalam belajar Qurdits dan juga Fiqih di dalam kelas. Adanya perbedaan metode mengajar membuat siswa lebih antusias pada apa yang disajikan oleh guru. Perubahan suasana kelas menjadi lebih aktif dan menyenangkan juga terjadi ketika diterapkannya media pembelajaran ini. Manfaat positif yang juga dirasakan langsung oleh guru adalah adanya kemudahan dalam mempersiapkan media game android ini dibandingkan dengan media manual atau tradisional lainnya. Penggunaan game tajwid petualangan dan juga Marbel Sholat ini juga memberikan ruang bagi guru untuk mengintegrasikan teknologi dengan pendidikan di zaman modern ini. Dampak positif di atas adalah dampak yang dirasakan oleh pengajar dan juga peserta didik dalam proses pembelajarannya. Sedangkan manfaat positif lainnya yang dapat dilihat secara tertulis adalah melalui hasil ujian siswa. Peningkatan pada nilai tugas tertulis dan praktik yang mencapai 10\%, juga membuktikan bahwa implementasi media pembelajaran ini berhasil dan dapat diterima dengan baik oleh siswa bukan hanya sebagai sarana bermain, tapi juga dimanfaatkan oleh guru sebagai sarana pembelajaran. 


\section{G. Referensi}

Ali, Muhammad. Kebijakan Pendidikan Menengah Dalam Perspektif Governance di Indonesia. Malang: UB Press, 2017.

Andy, Akhmad Yassin. Ilmu Tajwid Pedoman Membaca Al Qur'an. Jombang: Pelita Offset, 2010.

Annuri, Ahmad. Panduan Tahsin dan Ilmu Tilawah Al Quran. Jakarta: AlKautsar, 2010.

Arikunto, Suharsimi. Prosedur Penelitian: Suatu Pendekatan Praktek. Jakarta: Rieneka Cipta, 2002.

Lidinillah, Muiz. Game Pengenalan Ilmu Tajwid Berbasis Mobile dengan Metode Iterative Deeping. Skripsi------UIN Maulana Malik Ibrahim, Malang, 2014.

Mahmudin. "Efektivitas Metode Demonstrasi Dalam Pembelajaran Fiqih di Madrasah Ibtidaiyah". Jurnal Ilmiah Al-Madrasah, Vol.2, No.2, (Juni2018).

Muchlas, Makmuri. Perilaku Organisasi. Yogyakarta: Gadjah Mada Universitu Press, 2008.

Mundiri, Akmal., dan Zahra, Irma. "Implementasi Metode STIFIn dalam Meningkatkan Kemampuan Menghafal Al-Qur'an di Rumah Qur'an STIFIn Paiton Probolinggo". Jurnal Pendidikan Agama Islam (Journal of Islamic Education Studies), Vol. 5, No. 2 (2017).

Prihantini, Gita Sekar. Strategi Belajar. Malang: UMM Press, 2015.

Rahmawan, Putra Ditto. Pengembangan Game Edukatif Berbasis Android Sebagai Media Pembelajaran Akutansi di Kelas XI IPS SMA Negeri 1 Imogiri). Skripsi---------Universitas Negeri Yogyakarta, 2016.

Rakhmat, Jalaluddin. Psikologi Komunikasi. Bandung; PT. Rosda Karya, 2007.

Rumainur, Pengembangan Media Ajar Berbasis Multimedia. Tesis-------UIN Maulana Maliki Ibrahim, Malang, 2016.

Sa'diah, Khalimatus. “Kualitas Pembelajaran Al-Qur'an dengan Metode Tartila di TPQ Sabilun Najah Sambiroto Taman Sidoarjo”. Jurnal Pendidikan Agama Islam (Journal of Islamic Education Studies), Vol. 1, No. 2 (2013).

Siyam, Nur. "Factors Impacting Special Education Teachers' Acceptance and Actual Use of Technology". Education and Information Technologies, Vol. 24, No. 1 (2019).

Sugiyono. Metode Penilitian Kualitatif dan Kuantitatif R\&D. Bandung: Alfabeta, 2009. 
Suluh, Melkianus. "Persepsi Guru dan Peserta Didik Terhadap Proses Pembelajaran Flsika Berdasarkan Kurikulum 2013”. Jurnal Penelitian dan Pengkajian Ilmu Pendidikan e-Santika, Vol.2, No.2, (Juni-2019).

Usman, Husaini, \& Akbar, Purnomo Setiady. Metodologi Penelitian Sosial. Jakarta: Bumi Aksara, 2003.

Winarno, Budi, Kebijakan Publik, Teori \& Proses. Jakarta: PT. Buku Kita, 2006.

Wawancara:

M. Imron, Wawancara, Surabaya, 8 Maret 2020.

Najwatul Mufidah, Wawancara, Surabaya, 14 Maret 2020.

Nasywa Zahira, Wawancara, Surabaya, 2 Maret 2020.

Thalita Ifthina Zafira, Wawancara, Surabaya, 5 Maret 2020.

M. Andhika, Wawancara, Surabaya, 12 Maret 2020.

M. Zainul Musthofa, Wawancara, Surabaya, 24 Maret 2020.

Faruq Akmal Maulidin, Wawancara, Surabaya, 14 Maret 2020. 